Article

\title{
The Impact of Sea Shore Protection on Aeolian Processes Using the Example of the Beach in Rowy, N Poland
}

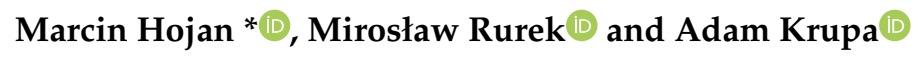 \\ Institute of Geography, Department of Landscape History Research, Kazimierz Wielki University, \\ Kościeleckich Square 8, 85-033 Bydgoszcz, Poland; mirur@ukw.edu.pl (M.R.); akrupa.geo@gmail.com (A.K.) \\ * Correspondence: homar@ukw.edu.pl
}

Received: 1 March 2019; Accepted: 16 April 2019; Published: 17 April 2019

check for updates

\begin{abstract}
The Polish Baltic Sea coast is subject to constant changes as a result of sea erosion on sandy and clayey sections. Sand accumulates only on a few sandy sections of the shore. There are various methods of protection limiting the negative impact of sea waves on the shore. In the city of Rowy, the coast was secured with the use of a comprehensive method (artificial reef, textile tube, spurs, and beach nourishment), which has mitigated the sea's negative impact. The beach has been widened. The upper part of the beach has been built up to the level of the foredune. Biotechnical protection has not been applied at the border between the beach and the foredune (fascine hurdles from brushwood, sand fences, and branches). This has caused wind blowing of sand from the beach to the forest growing on the foredune. The sand also covered the access road to holiday resorts. This was favored by the strong wind from the sea. Several morphological surveys were carried out, including topographic surveys and sedimentological samplings. The range of sand coverage and types of forms (aeolian shadows and drifts) were determined. Fifty eight samples of sand from various sources were collected for sedimentological analysis. Speed and directions of winds that occurred in 2001-2018 were also analyzed. Three wind speed criteria were distinguished: $\geq 4 \mathrm{~m} \cdot \mathrm{s}^{-1}, \geq 10 \mathrm{~m} \cdot \mathrm{s}^{-1}$, and $\geq 15 \mathrm{~m} \cdot \mathrm{s}^{-1}$, responsible for blowing away and transporting material. Results indicate that reconstruction of the beach to the height of the foredune, lack of biotechnical protection, and strong, coastal directions of the wind were the main factors responsible for increased aeolian transport of sand inland. Effects of aeolian processes such as those observed on the beach in Rowy were not observed elsewhere on the Polish coast of the South Baltic Sea, where beach nourishment was also performed.
\end{abstract}

Keywords: natural hazards; aeolian processes; technical infrastructure; beach nourishment; coastal protection

\section{Introduction}

Estimates related to the global trend of sea level rise indicate that by the end of the $21^{\text {st }}$ Century, the sea level may rise to $0.4 \mathrm{~m}$ and even to $0.6 \mathrm{~m}$ in relation to the current level [1]. Successive rising of the sea level will have an influence on the shaping of the coastal line, and the growing number of storm events will lead to the occurrence of storm floods in many places in the world [1].

Changes in the level of the Baltic Sea also depend on eustatic and glacio-isostatic movements. According to the results of observations conducted over the last 200 years, the fastest to rise is the Earth's crust in the area of the Gulf of Bothnia (up to $0.1 \mathrm{~m} \cdot \mathrm{a}^{-1}$ ). The southern Baltic coast rises at around $0.01 \mathrm{~m} \cdot \mathrm{a}^{-1}$ [2]. Other authors, considering climatic changes and glacio-isostatic movements, estimated that the southern coast of the Baltic Sea is rising at an average speed of $0.02 \mathrm{~m} \cdot \mathrm{a}^{-1}$ [3].

The Baltic coasts have a diverse geological structure. Sweden and Finland have solid rocks that are more resistant to erosion [4]. Other countries of the South Baltic coast, e.g., Poland, have sandy coasts, 
erosive and accumulative and clayey (moraine) erosive [5], which are subject to faster erosion than rocky coasts. The Baltic coasts are exposed to coastal erosion. Therefore, various methods, including nourishment, are used to secure beaches, dunes, and cliffs. Nourished beaches are subject to slower coastal erosion, but they are also exposed to aeolian erosion (e.g., the beach in Rowy).

Climatic change and rising sea level [4,6-9], as well as the increasing number of storms [8-11] contribute to erosion of the Polish coast of the South Baltic [11-14], including west of Rowy [15,16]. In addition, breakwaters securing outlets from seaports demonstrate an impact on the erosion processes of seacoasts in Poland; they disturb the process of longshore sediment transport [17-19].

The functioning of aeolian processes on the beach is also dependent on sea level and sea waves that change with wind speed [20]. On the southern coast of the Baltic, the sea level changes during the migration of barometric lows from the North Sea and the Norwegian Sea towards Lithuania, Latvia, or Estonia [17,21]. On the southern coast of the Baltic, the maximum sea level occurs when the sea level rise caused by barometric lows movement is added to the high waves caused by strong winds [20,22]. During storms, the waves flood the foreshore, the backshore, and the central part of the beach (depending on storm size). This reduces aeolian processes because the amount of sand to be transported by wind is smaller.

The kinetic energy of the wave in normal conditions is lost within the bottom between the sandbanks and the water line. During a storm, the loss of kinetic energy takes place in the upper part of the beach and at the foredunes and cliffs $[17,23]$. On the southern coast of the Baltic, in the case of stormy winds blowing at speeds $>15 \mathrm{~m} \mathrm{~s}^{-1}$, waves can reach 4-6 $\mathrm{m}$ [17].

Coastal erosion sediments are included in littoral transport. Surface currents are important to movement of sediment along the coast; they reach a speed of $0.2-2 \mathrm{~m} \mathrm{~s}^{-1}$ in the shallow water zone [24] and $0.2-3 \mathrm{~m} \mathrm{~s}^{-1}$ in the deep-water zone [25]. The occurrence of currents affects the supply of debris or loss of sediment in the coastal zone, as well as the formation of cyclic erosive and accumulative forms [17].

In many countries, the sea coast is a place of relaxation for people. Since the 1950s, coastal towns around the world (e.g., in France, Italy, Spain, Hawaii, the Caribbean, and Egypt) have seen intensive development of tourism [26]. In the 1990s and at the beginning of the $21^{\text {st }}$ Century, tourist facilities were also developed on established dunes [27]. In Rowy, the development of tourist facilities was initiated after the Second World War. The development of tourism has been particularly intense in Rowy in the last 20 years [27]. The result of this growth is the inflow of a large number of tourists. In summer, every day, 5-7 thousand people rest on the Rowy beach (the number of permanent residents is around 400). In the case of larger holiday destinations in Poland, for example Kołobrzeg and Miedzyzdroje, sometimes the number of tourists in summer exceeds 50 thousand a day. Coastal and beach erosion caused by sea waves contributes to towns becoming less attractive.

Various coastal structures are used to protect the seashore against negative effects of waves [9] depending on the geological structure and height of the seashore experiencing erosion. On the Polish Baltic coast, shore protection is mainly used in holiday destinations where infrastructure is at risk. Spurs, breakwaters, and underwater thresholds are just some of the means used in eroded parts of the shore (including in Kołobrzeg, Darłówek, Ustka) [18,28,29]. For protection of slopes, the bases of cliffs and dunes, stone bands, concrete blocks, stone covers, tetrapod covers, gabions, geotextiles, and geosynthetics are used (including in Trzęsacz, Ustronie Morskie, Jarosławiec, Jastrzębia Góra) [18,28,29]. To protect areas lying low above sea level, flood banks and counter-storms located parallel to the shore are used (Karwieńska Spit, Jamno Lake Spit) [18]. Biotechnical protection is often used to stabilize dunes (including fascine hurdles, planting grass), on most sections of the coasts with dunes [18]. One of the ways to protect the shore is to rebuild the beach by nourishment. This consists in taking sediment from the sea bottom and depositing it on the beach [30]. The location of the sediment collection site from the sea bottom is very important. When it is done too close to the shore, it can cause increased coastal erosion [31]. The depth of sand collection is also of significance [32]. Beach nourishment has been widely used on the Polish coast of the South Baltic since the 1980s and is carried 
out annually in many places [18]. Beach nourishment is used for protection of the sea shore in many European countries such as, for example, the Netherlands, Germany, Denmark, Lithuania, France, and Spain $[33,34]$. Beach nourishment also fosters the protection of seaside properties and beach widening for recreational purposes $[35,36]$. In the Netherlands, sand deposits for beach nourishment purposes are dredged at a depth $>20 \mathrm{~m}$ and $>20 \mathrm{~km}$ away from the shore [37]. Other studies referred to aeolian transport of sand from the nourished beach to foredunes [37,38]. During storms, the surface level of the beach is lowered. In between storms, aeolian processes refill and add height to the beach [29]. In some countries, e.g., in the USA, sand is removed/scraped with dozers to form artificial embankments along the beach. These embankments affect the flow of wind blowing from the sea and from the coast, hence enhancing the accumulation of sediments. The varied shape of ridges makes it possible to capture sand transported by wind or facilitates transport and accumulation of sand [38].

Before nourishment beaches are usually narrow. In Rowy, the beach before nourishment was from 5-10 m wide. The nourished beach widened to $60 \mathrm{~m}$. In Lithuania, the beach in Palanga after nourishment in 2012 was $75 \mathrm{~m}$ wide [34]. In the Netherlands, the width of a nourished beach can reach several hundred meters [37], which increases the surface affected by aeolian processes in comparison to the beach surface prior to nourishment $[39,40]$. In addition, a higher beach is drier, which increases its susceptibility to aeolian processes [41]. The intensity of aeolian transport on the beach depends on the direction of the wind. The wind's angle of attack on the beach determines the saturation length of the wind-sand transport path. The longest saturation of the wind-sand stream occurs along the beach and the shortest for directions perpendicular to the beach axis [20]. For Rowy, the direction along the beach is $235^{\circ}-55^{\circ}$, and the direction perpendicular to the beach is $325^{\circ}$.

In Rowy, sea erosion has reduced the width of the western part of the beach to a few meters. Work has been undertaken to increase the width of the beach and protect the shore against marine erosion. The first element of shore protection in Rowy was securing the foredune with a SoilTain@tube (HUESKER Synthetic GmbH, Gescher, Germany). The works were carried out in 2012 [42]. They comprised placing two synthetic sleeves in front of the dune and filling them with sediments from the sea. Each of these two synthetic sleeves was $25 \mathrm{~m}$ long, $4.5 \mathrm{~m}$ wide, and $1.9 \mathrm{~m}$ high (Figure 1). Ultimately, they were to be covered with a layer of sand with a thickness of $0.5 \mathrm{~m}$. After being covered, a small cliff was formed upon contact of the terrace and dunes [42].
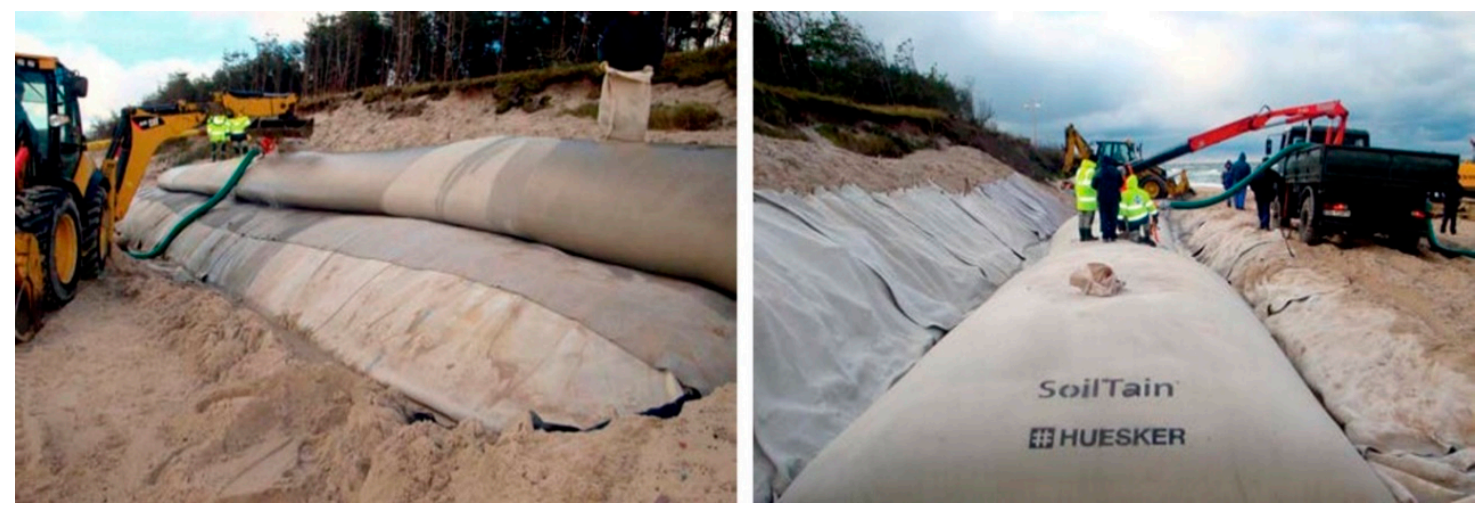

Figure 1. SoilTain ${ }^{\circledR}$ tube during construction works in Rowy, https://www.huesker.co.uk.

Because the shore on the sides of the tube was still subject to erosion in 2015-2016, artificial reefs (breakwater) with a total length of $750 \mathrm{~m}$ (five sections of $150 \mathrm{~m}$ each) were laid in the shoreface at a depth of 3.5-4 m, at a distance of $170 \mathrm{~m}$ from the shoreline [29]. Three spurs were built, and beach reconstruction was also carried out (Figure 2). The beach level after reconstruction was $0.7 \mathrm{~m}$ higher than assumed when using a tube. The height of the upper part of the beach was $3.0 \mathrm{~m}$, and the lack of a scarp and biotechnical protection at the beach and forest border resulted in increased aeolian transport of sand from the beach to the forest, to the access road, to holiday resorts, and to recreational areas (Figure 3A-C). 


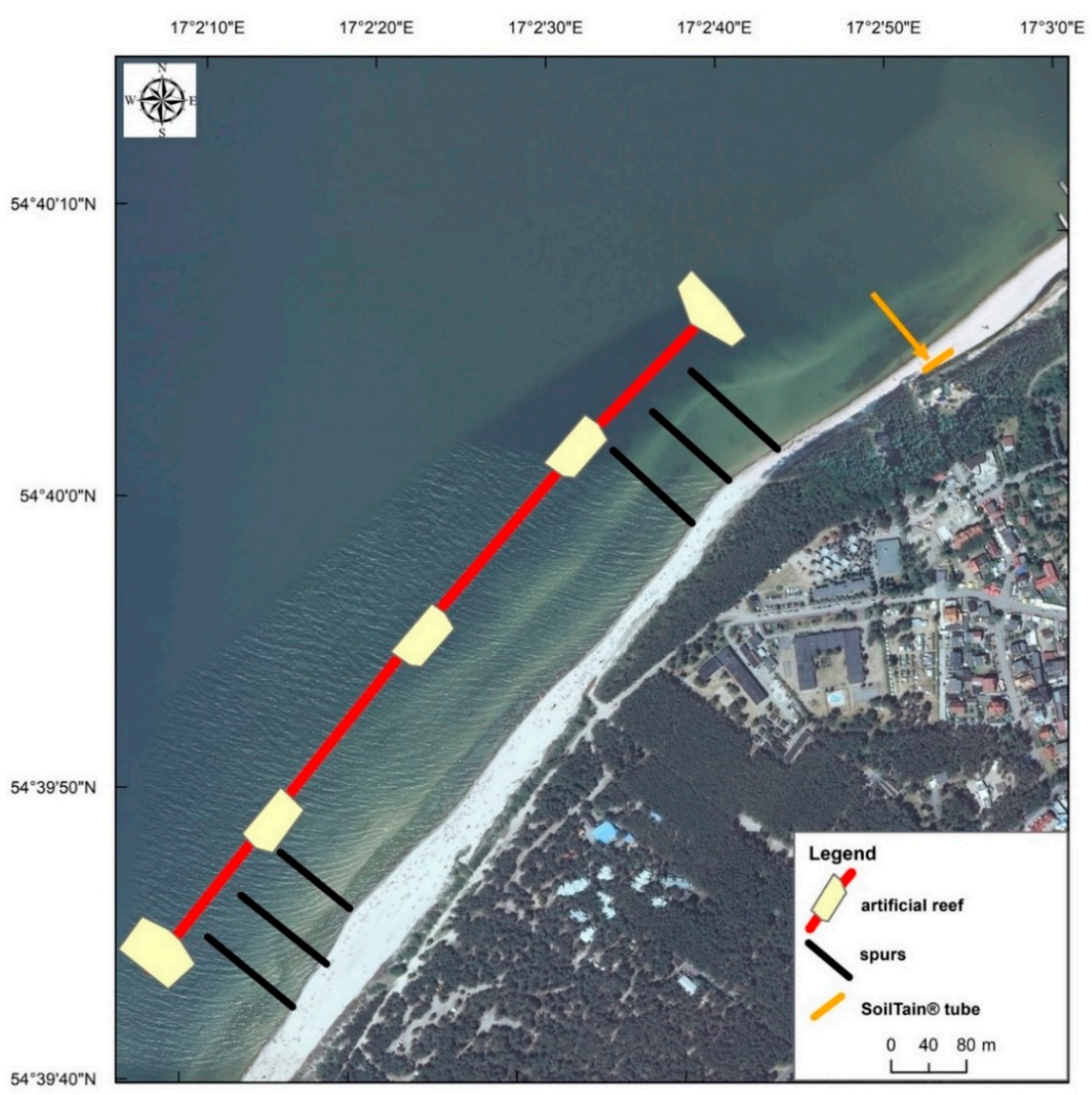

Figure 2. Types of protective elements used on the beach in Rowy.
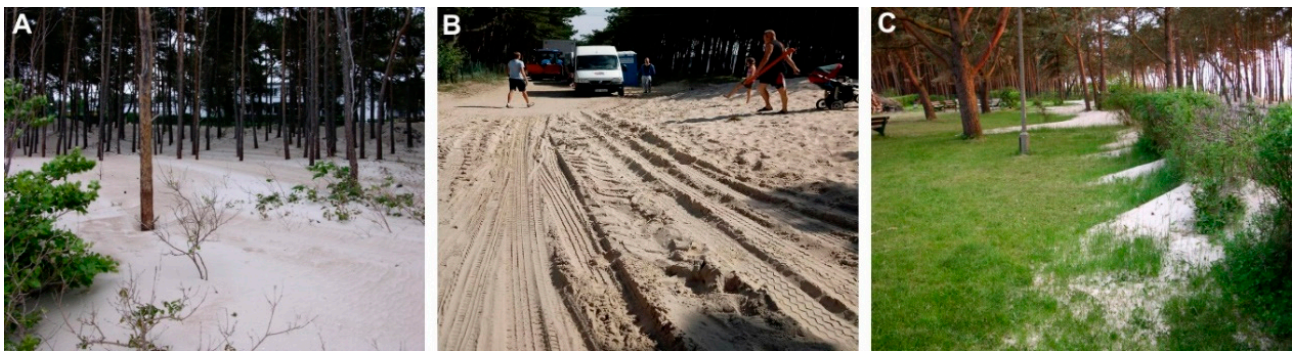

Figure 3. Examples of the effects of aeolian processes: (A) sand-covered forest, (B) sand-covered road,

(C) shadows and sand cover in a holiday resort.

The main purpose of this paper is to present the reconstruction of the beach in Rowy and the effect of this reconstruction on aeolian processes. The nourished beach was six-times wider than before the nourishment, which contributed to increased aeolian activity. The beach was nourished by sand deposits from the bottom of the sea. Since after nourishing, the sand from the surface of the beach was transported by wind to the foredune (forest), selected weather conditions (wind direction and speed) and geomorphological forms resulting from aeolian erosion and accumulation on the beach in Rowy are also presented.

\section{Study Area and Methods}

\subsection{Study Area}

The research area is located on the central coast, at the $218^{\text {th }} \mathrm{km}$ of the Polish shoreline (according to the Maritime Office), in the eastern part of Ustka Bay. Ustka Bay stretches from the $218^{\text {th }} \mathrm{km}$ (Rowy) to the $252^{\text {nd }} \mathrm{km}$ (Wicko Morskie) of the sea shore [43]. In geomorphological terms, it is the western 
part of the Gardnieńsko-Łebska Lowland. The coastal zone has a narrow strip of dunes adjacent to peat plains from the south. On the other hand, to the west of Rowy (and the dune strip), there is a series of frontal moraines determining the range of frontal moraines of the Vistulian Gardno phase [44]. East of Rowy lies the Łebsko Spit (constituting a strip of dunes) with a length of $40 \mathrm{~km}$, separating Gardno Lake, Łebsko Lake, and Sarbsko Lake from the sea.

The analyzed section of the bank was very narrow in recent years (the beach was up to $10 \mathrm{~m}$ wide and subjected to strong marine erosion). The degraded beach was built of fine- and medium-grained sands. The beach was clearly separated from the mainland by a low sandy scarp (about $3 \mathrm{~m}$ high), which was formed due to erosion of the foredune. The foredune was and is overgrown by a pine forest that forms a barrier against strong winds, and its width does not exceed $30 \mathrm{~m}$. To the west of the study area, foredunes are overgrown with grass vegetation and bushes (Figure 4).

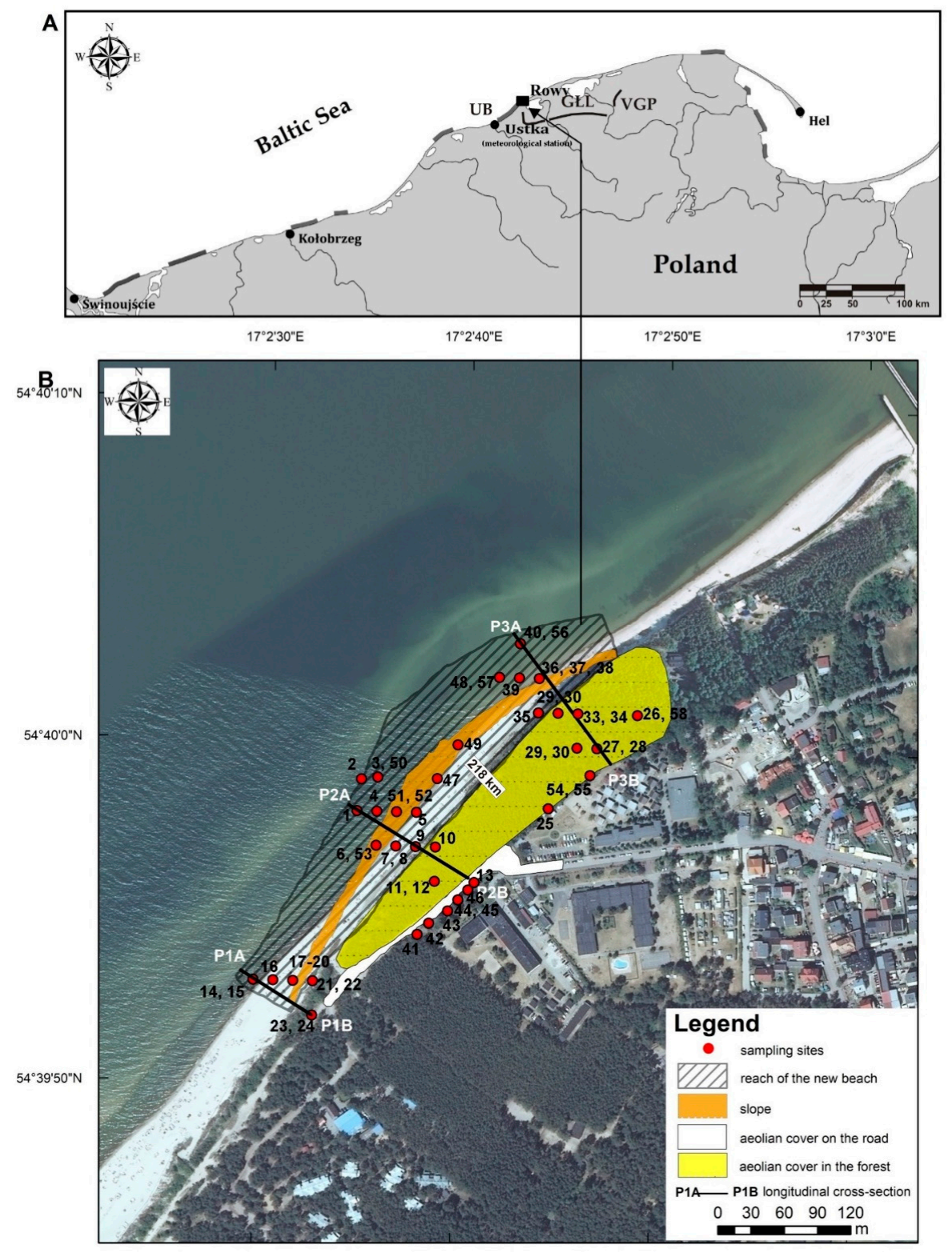

Figure 4. Location of the research area $(B)$ against the Polish coast of the Baltic Sea from the village of Piaski in the E (not shown on the map) to Świnoujście in the W (A). Places where beach profiles and sampling were made. The orthophotomap comes from 2011. Sand samples were collected on 27-28 May 2017. Dark grey line, erosive sections; UB, Ustka Bay; GŁL, Gardnieńsko-Łebska Lowland; VGP, Vistulian Gardno Phase. 
The coastline in the research area has a course of $235^{\circ}-55^{\circ}$, which favors the aeolian processes triggered by strong, onshore wind directions. Currently, the manmade beach consists of two parts: lower and upper. The lower part connects with the sea and is separated from the upper part by a slope with a tilt of $20^{\circ}-30^{\circ}$. The upper part of the beach has terrace characteristics. After beach nourishments, the beach was 60-100 m wide. Previously, sea erosion reduced the width of the beach to 5-10 m.

\subsection{Field Works and Data}

Morphological measurements of accumulative forms-sand coverage and shadows-were taken on the beach and in the forest. Forest density-the distance between trees-was measured. Three morphological profiles of the beach were made from the water line to the fence separating the forest from the road (Figure 4B). Outlines of the bottom beach, upper beach (terraces), and slope were also made. The width and length of the road covered by sand were also measured. GPS RTK (Real-Time Kinematics) was used for measurements.

Field tests were carried out on 27-29 May 2017, and sand samples were taken 11 months after the beach had been nourished. During field tests, sand samples were taken from the beach surface and from a depth of $20 \mathrm{~cm}$. Samples were collected using a small spatula with a width $0.05 \mathrm{~m}$. A total of 58 samples were collected, each of them weighing $0.2 \mathrm{~kg}$. Sampling took place on the beach (46 samples), in the forest (15 samples), and in the holiday resort (7 samples). On the beach, sand was sampled from accumulations forming shadows and micro-shadows. In the forest growing on the foredune, it was sampled from aeolian covers, shadows, and drifts. In the holiday resort, samples were taken from aeolian tongues. Sand samples were taken according to the east-west arrangement (lower and upper beach and forest). Several samples were collected in the forest and at the holiday resorts where there were aeolian forms (aeolian tongues). Sampling points can be found in Figure 1.

Collected samples were dried at $105^{\circ} \mathrm{C}$ for $6 \mathrm{~h}$. This was followed by grain size analysis using a Retsch AS200 shaker with sieves of the following mesh sizes: 63, 90, 125, 250, 500, 1000, and 2000 micrometers. The indices of [45] were calculated using Gradistat Beta 5.11.

Beach reconstruction was completed on 15 June 2016; therefore, the analysis of meteorological data was carried out for a period of 2 years from the completion of beach nourishment work, from 15 June 2016-14 June 2018. The background was formed by data for the long-term period of 2001-2017, since data collected every hour since 2001 are available. Only wind speeds and directions were used for analysis.

Meteorological data from the site were used in the analysis of the conditions of aeolian processes, https://danepubliczne.imgw.pl [46]. Data were analyzed for Ustka station WMO12115, 54 $35^{\prime} \mathrm{N}$ and $16^{\circ} 52^{\prime} \mathrm{E}$, located at a level of $6 \mathrm{~m}$ a.s.l. This station is located $15 \mathrm{~km}$ west of Rowy (Figure 4).

It was assumed that the activation of sandy sediments on the beach began at a minimum wind speed of $4-5 \mathrm{~m} \mathrm{~s}^{-1}$ [47]. The sand movement is activated at $4.4 \mathrm{~m} \mathrm{~s}^{-1}$ for the finest dry sands and at $10 \mathrm{~m} \mathrm{~s}^{-1}$ for moist material [48].

Three wind speed criteria were distinguished: $\geq 4 \mathrm{~m} \cdot \mathrm{s}^{-1}, \geq 10 \mathrm{~m} \cdot \mathrm{s}^{-1}$, and $\geq 15 \mathrm{~m} \cdot \mathrm{s}^{-1}$. The first wind speed range of transport initiation promotes transport of sand on the beach; the second interval favors transport of sand from the beach to the dune; the third wind speed interval favors transport of sand from the beach and dunes inland and can be compared to extreme processes. Such criteria of wind speed allowed determining the days on which aeolian transport from the beach could take place into the forest and on the road. Data regarding gusts of wind were also analyzed.

The impact of winds blowing from the sea towards foredunes was presented by [49]. Their study was based on the analysis of directions of the wind blowing towards the dune within the range from $0^{\circ}$ (onshore, perpendicular) to $90^{\circ}$ (cross-shore winds). Our work made use of an additional criterion, that is the participation of side onshore winds. The coastline in the research area runs from $235^{\circ}-55^{\circ}$. In the analysis of meteorological data, wind directions from the $250^{\circ}-40^{\circ}$ sector were assumed to be responsible for transporting sand into the forest. On the other hand, wind directions from the $250^{\circ}-300^{\circ}$ sector caused the formation of aeolian tongues behind the fence of the holiday resort. 


\section{Results}

\subsection{Characteristic of Meteorological Conditions}

Winds from the $180^{\circ}-225^{\circ}$ and $270^{\circ}$ sectors most often blew on the central Polish coast (near Ustka and Rowy) in the years 2001-2017 (Figure 5). Their share exceeded 10\%. The least frequent winds came from the northern sector, with a share not exceeding 5\%. Wind directions that were recorded in the periods 15-14 June 2017 and 15 June 2017-14 June 2018 were very close to the long-term period average (Figure 5). Despite the fact that winds from the $292.5^{\circ}-45^{\circ}$ sector were the least frequent, they had the highest morphogenetic velocities. In the long-term period, the highest wind speed was recorded on 18 November 2004 . It came to $26 \mathrm{~m} \cdot \mathrm{s}^{-1}$ for a direction of $300^{\circ}$. The maximum wind speed for the analyzed period (15 June 2016-14 June 2018) was $21 \mathrm{~m} \cdot \mathrm{s}^{-1}$ on 5 October 2016 for the direction $48^{\circ}-55^{\circ}$. In relation to the shoreline, this direction was onshore and, according to the adopted criteria, did not cause transport of sand into the land. The greatest gust of wind in the years 2001-2017 amounted to $35 \mathrm{~m} \cdot \mathrm{s}^{-1}$ on 18 November 2004.
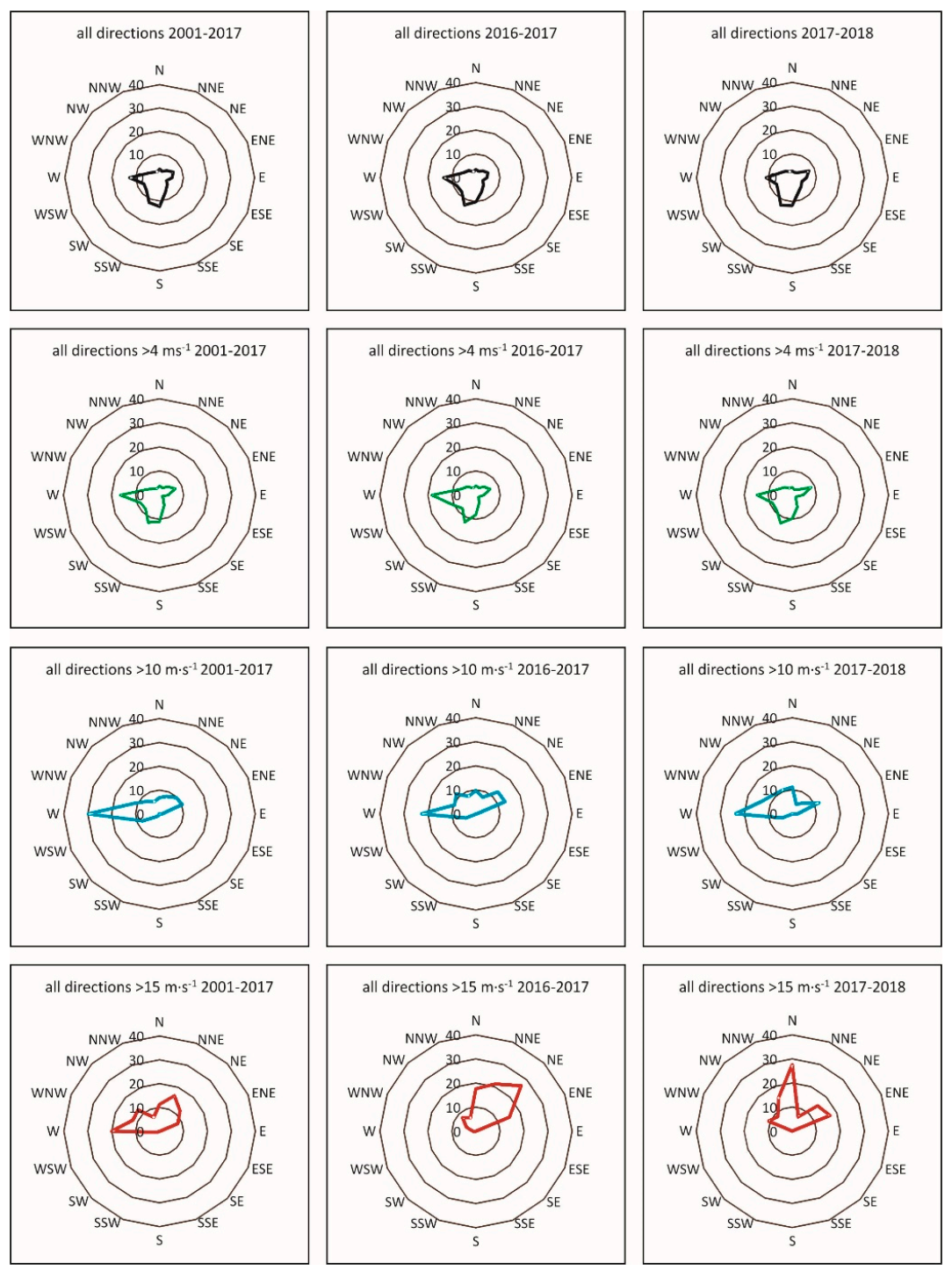

Figure 5. Percentage of all wind directions in the years 2001-2017 and in the long-term period of 15 June 2016-14 June 2017 (2016-2017) and 15 June 2017-14 June 2018 (2017-2018).

In 2001-2017, the number of days with wind speeds fostering aeolian processes was differentiated. For respective wind speeds, the average number of days was respectively: 260, 94, and 16 (Table 1). 
Table 1. Number of days with wind speeds allowing aeolian transport in 2001-2017.

\begin{tabular}{|c|c|c|c|}
\hline Year & $>4 \mathrm{~m} \mathrm{~s}^{-1}$ & $>10 \mathrm{~m} \mathrm{~s}^{-1}$ & $>15 \mathrm{~m} \mathrm{~s}^{-1}$ \\
\hline 2001 & 265 & 95 & 16 \\
\hline 2002 & 258 & 101 & 16 \\
\hline 2003 & 248 & 90 & 14 \\
\hline 2004 & 278 & 111 & 22 \\
\hline 2005 & 271 & 107 & 8 \\
\hline 2006 & 264 & 78 & 13 \\
\hline 2007 & 286 & 132 & 31 \\
\hline 2008 & 269 & 110 & 25 \\
\hline 2009 & 263 & 109 & 18 \\
\hline 2010 & 252 & 83 & 14 \\
\hline 2011 & 277 & 104 & 14 \\
\hline 2012 & 280 & 109 & 21 \\
\hline 2013 & 265 & 73 & 10 \\
\hline 2014 & 219 & 59 & 9 \\
\hline 2015 & 277 & 81 & 17 \\
\hline 2016 & 261 & 77 & 16 \\
\hline 2017 & 281 & 106 & 14 \\
\hline $\max$ & 286 & 132 & 31 \\
\hline $\min$ & 219 & 59 & 8 \\
\hline mean & 260 & 94 & 16 \\
\hline 2016-2017 & 272 & 87 & 22 \\
\hline 2017-2018 & 248 & 87 & 10 \\
\hline
\end{tabular}

In years 15 June 2016-14 June 2017 and 15 June 2017-14 June 2018 for wind directions allowing: (1) transport of sand along the beach $\left(235^{\circ}-55^{\circ}\right)$, (2) transport of sand to dunes $\left(250^{\circ}-40^{\circ}\right)$, and (3) emergence of aeolian shadows in the holiday resort $\left(250^{\circ}-300^{\circ}\right)$, the number of days with wind speeds $>4 \mathrm{~m} \cdot \mathrm{s}^{-1}$ and $>15 \mathrm{~m} \cdot \mathrm{s}^{-1}$ was differentiated. On the other hand, for wind speeds $>10 \mathrm{~m} \cdot \mathrm{s}^{-1}$ the number of days with designated wind directions was similar (Table 2).

Table 2. Number of days with wind speeds allowing aeolian transport in the measuring years.

\begin{tabular}{|c|c|c|c|c|}
\hline Period & $>4 \mathrm{~m} \cdot \mathrm{s}^{-1}$ & $>10 \mathrm{~m} \cdot \mathrm{s}^{-1}$ & $>15 \mathrm{~m} \cdot \mathrm{s}^{-1}$ & $>20 \mathrm{~m} \cdot \mathrm{s}^{-1}$ \\
\hline \multicolumn{5}{|c|}{$235^{\circ}-55^{\circ}$} \\
\hline 15 June 2016-14 June 2017 & 272 & 87 & 22 & 3 \\
\hline 15 June 2017-14 June 2018 & 248 & 87 & 10 & 1 \\
\hline \multicolumn{5}{|c|}{$250^{\circ}-40^{\circ}$} \\
\hline 15 June 2016-14 June 2017 & 243 & 73 & 16 & 1 \\
\hline 15 June 2017-14 June 2018 & 214 & 79 & 10 & 1 \\
\hline \multicolumn{5}{|c|}{$250^{\circ}-300^{\circ}$} \\
\hline 15 June 2016-14 June 2017 & 181 & 46 & 2 & 0 \\
\hline 15 June 2017-14 June 2018 & 171 & 44 & 3 & 0 \\
\hline
\end{tabular}

The beginning of covering the forest with sand from the beach was on 6 July 2016 on the day when a wind speed of $10-19 \mathrm{~m} \cdot \mathrm{s}^{-1}$ was recorded from directions $258^{\circ}-336^{\circ}$. Speed equal to and higher than $15 \mathrm{~m} \cdot \mathrm{s}^{-1}$ occurred for six hours. Another day favoring aeolian transport to the forest was on 14 July 2016. On that day, the wind speed ranged from $10-17 \mathrm{~m} \cdot \mathrm{s}^{-1}$, blowing from directions of $348^{\circ}-27^{\circ}$ (eight hours $>15 \mathrm{~m} \cdot \mathrm{s}^{-1}$ ). By December 2016, there were eight more days with wind speeds exceeding $15 \mathrm{~m} \cdot \mathrm{s}^{-1}$, whereas on 27 and 28 November, the duration of such wind amounted to $18 \mathrm{~h}$ in total from directions $1^{\circ}-23^{\circ}$. The beginning of December brought continuation of strong winds from the northwest and the north. From December 25, wind speed increased due to the approaching Storm Barbara, during which the highest wind speed was recorded on December 27 at 3:00 and 5:00 in the 
morning. During the entire day, wind speed exceeded $13 \mathrm{~m} \cdot \mathrm{s}^{-1}$, reaching a maximum of $18 \mathrm{~m} \cdot \mathrm{s}^{-1}$, with gusts up to $27 \mathrm{~m} \cdot \mathrm{s}^{-1}$. The direction of wind changed from $247^{\circ}$ to $357^{\circ}$. On that day, the road was covered with sand for the first time. A week later, Storm Axel appeared with a wind speed approaching $21 \mathrm{~m} \cdot \mathrm{s}^{-1}$, with gusts up to $27 \mathrm{~m} \cdot \mathrm{s}^{-1}$. For $27 \mathrm{~h}$, wind speed exceeded $15 \mathrm{~m} \cdot \mathrm{s}^{-1}$. At this time, wind direction changed from $290^{\circ}$ to $49^{\circ}$. For the second time, the road was covered with sand coming from the nourished beach. The next days, when the sand was accumulated on the road (at a smaller scale), were: 24 February and 16 and 22 April 2017; on these days, the recorded wind speed was $15 \mathrm{~m} \cdot \mathrm{s}^{-1}$ and greater. In the second year subject to analysis, wind blowing on 29 October 2017 was significant. On this day, a wind speed in the range of $16-20 \mathrm{~m} \cdot \mathrm{s}^{-1}$ was recorded for $18 \mathrm{~h}$ with wind gusts reaching a maximum of $24 \mathrm{~m} \cdot \mathrm{s}^{-1}$. In the remaining days, separated according to the criteria, wind speed equal to and greater than $15 \mathrm{~m} \cdot \mathrm{s}^{-1}$ occurred briefly and had no relevant morphogenetic significance.

Wind gusts $>10 \mathrm{~m} \cdot \mathrm{s}^{-1}$ recorded at lower wind speeds also demonstrated morphogenetic significance. For both analyzed years, the number of days with gusts of wind was almost the same and amounted to 115 in the period of 15 June 2016-14 June 2017 and 113 in the period of 15 June 2017-14 June 2018. Distribution of wind gusts was also similar in October-April (78 and 79 days), when the frequency of gusts was $10 \mathrm{~m} \cdot \mathrm{s}^{-1}$, twice as high as in May-September (37 and 34 days). The predominance of wind gusts in the winter half of the year is mainly due to atmospheric circulation and movements of the western and northwest sectors in this period.

\subsection{Morphological Analysis of the Research Area}

At medium sea levels (500 cm NN (Normal-Null)), aeolian processes were observed over the entire width of the reconstructed beach (for wind direction along the beach). Field observations have shown that for onshore directions, the intensity of aeolian transport was the highest in the middle and upper part of the beach. Because the level of the beach was equal to the level of the foredunes, the sand was transported smoothly into the forest with a decrease in wind speed and transport intensity caused by trees.

With sea levels higher than average $(>500 \mathrm{~cm} \mathrm{NN})$ and during storm accumulations, the lower part of the beach formed naturally is gradually flooded by sea waves up to the base of the dunes and the foot of the reconstructed beach (depending on the beach profile and sea level). Hence, the beach area subject to aeolian processes decreases with the range of waves. The surface of the reconstructed beach (middle and upper beach) is not flooded by waves (except extreme storm accumulations); therefore, the entire surface of the reconstructed beach can be blown by wind. Aeolian transport was observed in the middle and upper part of the beach. At the same time, this area is a source of sand supply for aeolian transport towards the shore (for Rowy, sand was transported towards the forest and recreational resorts).

\subsubsection{Sand Coverage in the Forest and at the Road}

Construction of an artificial reef, spurs, and beach nourishment and forming the nourished beach were completed in mid-June 2016. Sand from the beach was blown away into the forest for the first time in July 2016. The sand coverage, during subsequent strong winds, moved inland, extending deeper and deeper into the forest. Conversations with the residents in Rowy, which we carried out in May 2017, helped to determine the beginning of blowing sand into the forest and the access road to holiday resorts. On 27 December 2016, during Storm Barbara, sand covered the road for the first time. Ten to twelve sand trailers were removed from the backfilled road (trailer capacity was six tons), so the quantity of exported sand was about $60-72$ tons. Assuming $1 \mathrm{~m}^{3}$ of dry sand weighs 1.52 tons, this gives the volume of sand accumulated on the road at about $39.5-47.5 \mathrm{~m}^{3}$. However, this value seems to be understated, as sand was removed only from the road, while it remained before the fence. A few days later (4 January 2017), there was strong wind connected with Storm Axel, and the road was buried once again. Sand backfilled the road four times by May 2017. 
Since the transport of sand from the reconstructed beach to the forest and the road is a result of winds from the seaward sectors, the formula for incomplete saturation of the wind stream was used for the calculation. The values obtained by [20] were averaged to the value: $0.004525 \mathrm{~kg} \cdot \mathrm{m}^{-1} \cdot \mathrm{s}^{-1}$. Recalculation gave a sand transport value of $390.96 \mathrm{~kg} \cdot \mathrm{m}^{-1} \cdot$ day $^{-1}\left(0.26 \mathrm{~m}^{3} \mathrm{~m}^{-1}\right.$ day $\left.^{-1}\right)$ at a wind speed of 7-11 $\mathrm{m} \mathrm{s}^{-1}$. According to [49], the directions of onshore to cross-shore winds model the surface and the ridge of the foredune. This has an influence on the accumulation of sediments within and outside the foredune.

Diversified thickness and width of the sandy covers do not allow to clearly determine the amount of the volume of material accumulated in the forest. To show the volume of the material being recycled, its quantity for one place was calculated. The averaged values of the length, width and thickness of the sand cover in the forest were adopted. It was calculated that a belt with a length of $50 \mathrm{~m}$, a thickness of $0.3 \mathrm{~m}$ and a width of $1 \mathrm{~m}$ contains $15 \mathrm{~m} 3$ of sand (22.8 tons). Using the formula for incomplete wind stream saturation [20], it was calculated that in the period from 15 June 2016-14 June 2017, six tons of sand with a width of $1 \mathrm{~m}$ should be deposited in the aeolian lane (the following were recorded in this period: $638 \mathrm{~h}$ with a wind speed of $10 \mathrm{~m} \mathrm{~s}^{-1}, 100 \mathrm{~h}$ with a wind speed of $15 \mathrm{~m} \mathrm{~s}^{-1}$, and seven hours with a wind speed of $20 \mathrm{~m} \mathrm{~s}^{-1}$ ). It follows from the above that the actual aeolian transport value was three-times higher than that calculated from the formula for incomplete wind stream saturation. However, this is a big simplification; the calculations do not take into account speeds exceeding 10, 15, and $20 \mathrm{~m} \mathrm{~s}^{-1}$ and gusts of wind.

\subsubsection{Accumulative Forms on the Beach}

On the new beach (Figure $6 \mathrm{~A}-\mathrm{C}$ ), sand was accumulated in the form of aeolian shadows (Figure 6D-F), which formed behind clumps of vegetation, branches, and other obstacles. Aeolian shadows [50] reached a height of $0.1-0.5 \mathrm{~m}$, a width of $0.2-1 \mathrm{~m}$, and a length up to 2-3 m, depending on the obstacle's size and height. Micro-shadows formed anywhere with even the smallest obstacles (Figure 6G). They were formed by small stones, cones, or even shells. Dimensions of micro-shadows (width, length, and height) reached a maximum of $0.02-0.04 \mathrm{~m}$. Aeolian shadows and micro-shadows are ephemeral forms. They quickly dissolve due to wind blowing from other directions. What is more, in the summer season, they are trampled and destroyed by tourists. Subsequent winds give rise to new forms.

There are also effects of aeolian erosion in the form of pavement, made of coarse sand and shells, which can be observed on the beach (Figure 6F,G). Surfaces covered with aeolian pavement were clearly visible on the beach surface due to grain size, as well as their mineral composition (Figure 6C,D,F). Hollows were formed before bigger obstacles, in other words deflation niches: traces of wind flowing around the obstacle. In the forest, behind the trees, aeolian drifts and shadows were found. They reached a length of $0.7 \mathrm{~m}-2 \mathrm{~m}$ and a width of $0.2 \mathrm{~m}-0.5 \mathrm{~m}$. Most frequently, they were low forms with heights of $0.2-0.5 \mathrm{~m}$ (Figure $6 \mathrm{H}-\mathrm{J}$ ). The speed of wind blowing from inland directions and its long-lasting impact also led to backfilling of the road and the neighboring holiday resorts (Figure 6K-M). The total volume of sand blown and accumulated outside the beach was difficult to estimate, but it reached a value of around $50 \mathrm{~m}^{3}$ only on a section of the buried road during one event. The average thickness of the sand coverage and accumulation in the forest was $0.3 \mathrm{~m}$. In total, about $6000 \mathrm{~m}^{3}$ of sand were found in the forest. The beach area has dropped as a result of aeolian processes by $0.17-0.25 \mathrm{~m}$ per year.

In the holiday resort, there were five covers with aeolian tongues of different sizes. The length of covers and tongues ranged from $4.4 \mathrm{~m}-10.4 \mathrm{~m}$. Width ranged from $1.4 \mathrm{~m}-3 \mathrm{~m}$, and height (thickness) ranged from $0.25 \mathrm{~m}-0.5 \mathrm{~m}$ (Figure $6 \mathrm{~L}, \mathrm{M}$ ). It was calculated that the amount of sand deposited in these forms was around $11-15 \mathrm{~m}^{3}$. 

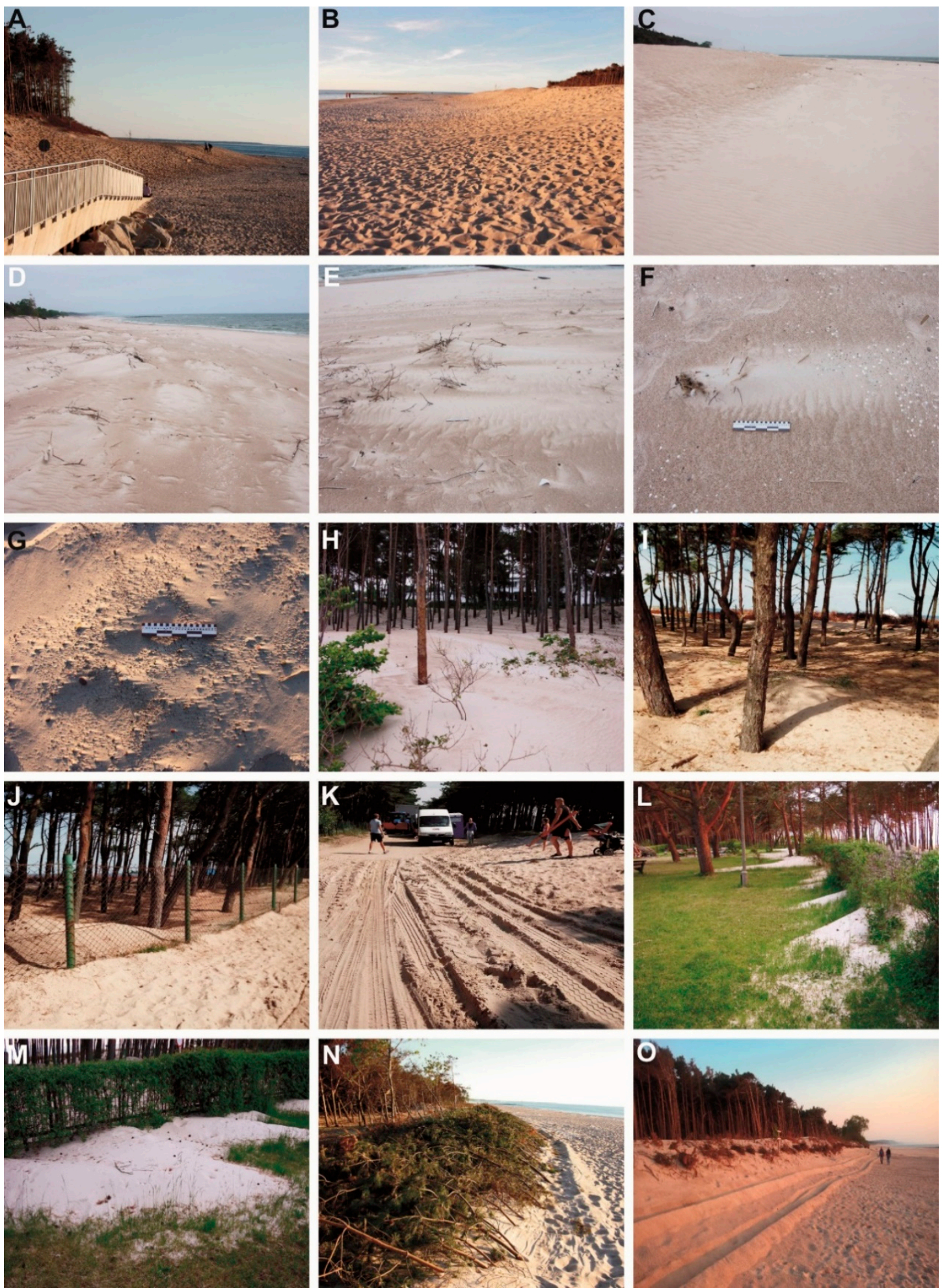

Figure 6. Morphology of the analyzed section of the beach and its surroundings (photographs taken on 27-28 May 2017). A-C-new beach, D-F-aeolian shadows, F-G-pavement, made of coarse sand and shells, $\mathbf{H}-\mathbf{J}$ - sand coverage and aeolian drifts and shadows behind the trees, $\mathbf{K}-$ sand on the road, $\mathbf{L}-\mathbf{M}$-aeolian tongues in holiday resort, $\mathbf{N}-\mathbf{O}$ - branches of coniferous and deciduous trees on the border between the beach and the forest.

The new level of the upper part of the beach was made equal to the level of the dunes covered with a forest. At the border between the beach and the forest, no protection against sand being blown 
into the forest was used. Biotechnical protection was applied in May 2017, after 10 months of beach nourishment. On the border between the beach and the forest, there were branches of coniferous and deciduous trees whose task was to capture the sand (Figure 6N,O). After a year, it turned out that their task was fulfilled as a dune ridge had formed on them. At that time, there was no sign of the sand covering the road, which indicates the effectiveness of biotechnical protection. Lack of transport of sand from the beach to the road (apart from effective protection) was also influenced by wind conditions; at that time, no strong morphogenetic winds were recorded.

\subsection{Sedimentological Analysis}

Results of grain size analysis in 58 samples taken from sandy accumulative and deflation forms indicated sedimentological variation of sediments (Table 3). Figure 1 shows the location of sandy samples taken. Because several samples were collected at a short distance from each other, not all points are included in the figure. In most samples (56), sorting fell in the range of 0.3-1.0, indicating transport of sand under similar conditions (Figure 7). The mean grain diameter emphasized differentiation in grain size and sediment type. In this case, the largest number of samples (49 samples) fell in the range of 1.2-2.0 phi (logarithmic scale), which indicates large similarity of sediment. The sand coming from the surface of the beach (both bottom and erected) was fine and medium grained, moderately well and well sorted. Samples from the aeolian pavement were coarse grained and well sorted. Only the P1P1 sample, which came from the breaking wave zone, was very well sorted, and the coarse sand sample from point P1P7 was poorly sorted (Table 3). Samples taken from shadows and sand coverage contained fine-grained and medium-fine sand, which was well sorted. Samples from aeolian pavement in the vicinity of aeolian shadows were coarse and moderately and well sorted. Samples from the sand coverage in the holiday resort (Samples Nos. 41-44) did not differ in diameter and sort from other samples from the beach (14-17). This testifies to the homogeneous material found in the source of deflation: the nourished beach.

Sand coverage was accumulated in the forest and near the recreational resort. The sand coverage by the recreational resort had a thickness of $0.25-0.5 \mathrm{~m}$. There were sandy shadows formed behind the trees on the sand coverage accumulated in the forest. The analysis of grain size in seven samples taken from sand coverage (Sample Nos. 27, 28, 29, 33, 34, 42, 55) indicates the presence of medium-grained sand. In one sample, fine-grained sand was observed (Sample No. 58), and in Sample No. 26, there was coarse-grained sand. The sorting in samples was well and moderately well. Sedimentological indicators showed that the sedimentation environment was similar depending on the location of covers. The "well" value for sorting and moderately fine granulation pointed to small differences in wind speed. The location of forms (forest and resort behind the forest) indicated high speeds of winds shaping these forms. The thicker fraction was located in the deflationary depression. Thicker grains were not found on the surface of covers. Accumulative forms on the beach and in the forest were created again or refreshed after each strong wind. Beach surface erosion resulted in the formation of desert pavement of shells or coarse-grained sand (the beach was nourished with sand from the sea bottom). Drifts formed at the back of the dunes. Sedimentological indicators showed the highest share of medium-grained sand (Sample Nos. 10, 11, 12, 21, 22, 30,54). In only one sample, the mean diameter corresponded to fine-grained sand (Sample No. 35). Sorting in the analyzed samples showed signs of well sorting (Sample Nos. 12, 22, 35, 54) and moderately well sorting (Sample Nos. 10, 11, $21,30)$. Sedimentological indicators pointed to the participation of winds of different velocity. These forms were piled up in similar wind conditions.

The most numerous accumulative forms were aeolian shadows and micro-shadows. They were formed on the lower beach (Sample Nos. 40, 50, 56, 57), the slope (Sample Nos. 47, 49, 51, 52, 53), and the upper beach (Sample Nos. 5, 7, 8) in the forest and holiday resort (Sample Nos. 41, 43, 44, 45, 46). The analysis of grain size for samples taken from different places showed that the micro-shadows were made of fine-grained sand (Sample Nos. 45, 52, 56, 57) and aeolian shadows from medium-grained sand (Sample Nos. 5, 8, 40, 41, 43, 44, 47, 50, 51, 53) and coarse-grained sand (Sample Nos. 7, 46, 49). Sorting 
in all samples was varied. Sorting was well in 11 samples (Sample Nos. 40, 41, 43, 44, 45, 47, 51, 52, 53, 56, 57). Two samples were moderately sorted (Sample Nos. 8, 49), and two samples were moderately well sorted (Sample Nos. 5, 50). One sample showed weak sorting (Sample No. 7). Sedimentological indicators pointed to winds blowing at different speeds. Shadows were formed over a longer period of time compared to micro-shadows. As shown by the analysis, the same characteristics were shared by samples taken from areas exposed to wind (beach) and sediments accumulated in the forest, where the speed of the wind stream decreases. The location of accumulative forms had also influenced the diversification of sedimentological indicators. Coarser grains may indicate the participation of winds at higher speeds, while the location of these grains on the slope between the restored beach, the upper edge of this slope, and on the lower beach indicates the impact of winds blowing at different speeds. Besides, poor sorting was found only in one sample (Sample No. 7). During the accumulation of sand coverage and forms, the wind conditions for deflation and accumulation of sediments were similar. Among deflation and accumulation on the beach and beyond, we have the opportunity to trace wind conditions based on the accumulative forms found on the beach. Fine-grained sands were observed in accumulative forms, i.e., aeolian shadows and drifts, whereas coarse fractions were observed in deflationary depressions before an obstacle (e.g., tree, clump of grass, etc.) or on the sides of obstacles or aeolian shadows (Sample No. 26). As for shadows located near the recreational resort, samples of aeolian sediments were collected in the same way as samples in the forest (Sample No. 46). Sample Nos. 10 and 30 were taken from drifts in the initial forest zone. They shared similar sedimentological characteristics (sorting and mean diameter; Table 3).

Table 3. Folk and Ward [45] parameters for all sand samples.

\begin{tabular}{|c|c|c|c|c|c|c|c|}
\hline $\begin{array}{l}\text { Sample } \\
\text { Number }\end{array}$ & $\begin{array}{c}\text { Mean Diameter } \\
\text { phi }\end{array}$ & $\begin{array}{c}\text { Sorting } \\
\text { phi }\end{array}$ & $\begin{array}{c}\text { Kurtosis } \\
\text { phi }\end{array}$ & $\begin{array}{c}\text { Skewness } \\
\text { phi }\end{array}$ & $\begin{array}{c}\text { Sorting } \\
\text { phi }\end{array}$ & $\begin{array}{c}\text { Mean Diameter } \\
\text { phi }\end{array}$ & D50 phi \\
\hline 1 & coarse & very well & 0.75 & 0.062 & 0.332 & 0.997 & 0.984 \\
\hline 2 & medium & well & 1.231 & 0.001 & 0.39 & 1.736 & 1.74 \\
\hline 3 & fine & well & 0.932 & -0.055 & 0.364 & 2.063 & 2.099 \\
\hline 4 & medium & well & 0.987 & 0.041 & 0.397 & 1.885 & 1.848 \\
\hline 5 & medium & mod. well & 1.008 & -0.151 & 0.609 & 1.6 & 1.649 \\
\hline 6 & coarse & moderately & 0.852 & -0.012 & 0.989 & 0.992 & 0.958 \\
\hline 7 & coarse & poorly & 0.843 & -0.023 & 1.02 & 0.952 & 0.935 \\
\hline 8 & medium & moderately & 0.999 & 0.006 & 0.986 & 1.023 & 0.951 \\
\hline 9 & coarse & moderately & 0.971 & 0.02 & 0.931 & 0.893 & 0.851 \\
\hline 10 & medium & mod. well & 0.994 & -0.094 & 0.566 & 1.585 & 1.613 \\
\hline 11 & medium & mod. well & 1.003 & -0.139 & 0.682 & 1.392 & 1.45 \\
\hline 12 & medium & well & 0.968 & 0.008 & 0.462 & 1.753 & 1.75 \\
\hline 13 & medium & well & 1.208 & -0.105 & 0.483 & 1.71 & 1.733 \\
\hline 14 & medium & mod. well & 0.968 & -0.087 & 0.58 & 1.626 & 1.642 \\
\hline 15 & medium & moderately & 0.923 & -0.018 & 0.733 & 1.331 & 1.315 \\
\hline 16 & medium & well & 1.006 & -0.026 & 0.455 & 1.794 & 1.792 \\
\hline 17 & medium & well & 0.848 & 0.054 & 0.351 & 1.936 & 1.909 \\
\hline 18 & medium & well & 0.958 & 0.02 & 0.398 & 1.939 & 1.917 \\
\hline 19 & medium & mod. well & 1.42 & -0.269 & 0.633 & 1.612 & 1.67 \\
\hline 20 & medium & mod. well & 1.468 & 1.42 & -0.269 & 0.633 & 1.612 \\
\hline 21 & medium & mod. well & 1.409 & 1.468 & 1.42 & -0.269 & 0.633 \\
\hline 22 & medium & well & 1.038 & 0.041 & 0.437 & 1.9 & 1.87 \\
\hline 23 & fine & well & 1.092 & -0.05 & 0.38 & 2.127 & 2.168 \\
\hline 24 & fine & well & 0.921 & -0.051 & 0.367 & 2.053 & 2.089 \\
\hline 25 & medium & mod. well & 1.158 & -0.166 & 0.61 & 1.807 & 1.864 \\
\hline 26 & coarse & well & 1.263 & 0.036 & 0.431 & 0.662 & 0.691 \\
\hline 27 & medium & mod. well & 1.002 & -0.079 & 0.523 & 1.702 & 1.717 \\
\hline 28 & medium & mod. well & 0.982 & -0.083 & 0.582 & 1.41 & 1.456 \\
\hline 29 & medium & mod. well & 0.909 & 0.086 & 0.55 & 1.266 & 1.252 \\
\hline 30 & medium & mod. well & 0.984 & -0.045 & 0.551 & 1.64 & 1.643 \\
\hline
\end{tabular}


Table 3. Cont.

\begin{tabular}{cccccccc}
\hline $\begin{array}{c}\text { Sample } \\
\text { Number }\end{array}$ & $\begin{array}{c}\text { Mean Diameter } \\
\text { phi }\end{array}$ & $\begin{array}{c}\text { Sorting } \\
\text { phi }\end{array}$ & $\begin{array}{c}\text { Kurtosis } \\
\text { phi }\end{array}$ & $\begin{array}{c}\text { Skewness } \\
\text { phi }\end{array}$ & $\begin{array}{c}\text { Sorting } \\
\text { phi }\end{array}$ & $\begin{array}{c}\text { Mean Diameter } \\
\text { phi }\end{array}$ & D50 phi \\
\hline 31 & medium & mod. well & 1.03 & -0.094 & 0.534 & 1.644 & 1.667 \\
32 & medium & mod. well & 1.02 & -0.071 & 0.525 & 1.583 & 1.602 \\
33 & medium & mod. well & 1.077 & -0.141 & 0.662 & 1.393 & 1.449 \\
34 & medium & mod. well & 0.977 & -0.055 & 0.601 & 1.367 & 1.398 \\
35 & fine & well & 1.013 & -0.032 & 0.413 & 2.131 & 2.161 \\
36 & medium & well & 1.006 & 0.039 & 0.424 & 1.949 & 1.931 \\
37 & fine & well & 1.043 & -0.068 & 0.389 & 2.116 & 2.161 \\
38 & fine & well & 0.932 & -0.116 & 0.355 & 2.066 & 2.113 \\
39 & medium & well & 0.98 & -0.147 & 0.446 & 1.889 & 1.903 \\
40 & medium & well & 0.925 & 0.003 & 0.384 & 1.924 & 1.898 \\
41 & medium & well & 0.943 & -0.046 & 0.459 & 1.863 & 1.868 \\
42 & medium & well & 1.126 & 0.049 & 0.396 & 1.824 & 1.793 \\
43 & medium & well & 0.907 & 0.018 & 0.382 & 1.96 & 1.946 \\
44 & medium & well & 1.003 & 0.047 & 0.399 & 1.871 & 1.833 \\
45 & fine & well & 0.926 & -0.038 & 0.377 & 2.052 & 2.087 \\
46 & coarse & moderately & 1.099 & 0.074 & 0.725 & 0.084 & 0.106 \\
47 & medium & well & 0.9753 & -0.043 & 0.394 & 1.611 & 1.648 \\
48 & coarse & well & 1.371 & 0.073 & 0.466 & 0.652 & 0.682 \\
49 & coarse & moderately & 0.986 & 0.105 & 0.995 & 0.694 & 0.532 \\
50 & medium & mod. well & 0.977 & 0.047 & 0.502 & 1.404 & 1.393 \\
51 & medium & well & 0.938 & -0.052 & 0.394 & 1.992 & 2.01 \\
52 & fine & well & 0.918 & -0.04 & 0.385 & 2.003 & 2.019 \\
53 & medium & well & 0.968 & 0.074 & 0.406 & 1.988 & 1.977 \\
54 & medium & well & 1.02 & -0.043 & 0.456 & 1.805 & 1.803 \\
55 & medium & well & 1.027 & 0.038 & 0.4 & 1.86 & 1.824 \\
56 & fine & well & 0.826 & -0.003 & 0.355 & 2.01 & 2.024 \\
57 & fine & well & 0.938 & -0.062 & 0.372 & 2.06 & 2.099 \\
58 & fine & well & 0.922 & -0.021 & 0.377 & 2.052 & 2.081 \\
\hline & & & & & & \\
\end{tabular}

To sum up, the analysis of sedimentological indicators (Figure 7) showed that samples can be split into three groups. Only three samples (20,21 and 46) did not make reference to similarities in sorting for other samples. When these groups were associated with accumulative forms, it can be seen that only Group 2 (Samples 2, 26, and 48) and Group 3 (Samples 6, 7, 8, 9, and 49) occurred in identical accumulative forms (Group 2, micro-shadows, Group 3, shadows). Samples from Group 1 (most numerous) derived from different forms (sand coverage, shadows, drifts, tongues). A similar distribution in these groups (Group 1) points to similar wind speeds. Transport distance and share of coarser sand fractions were factors significant for other groups.

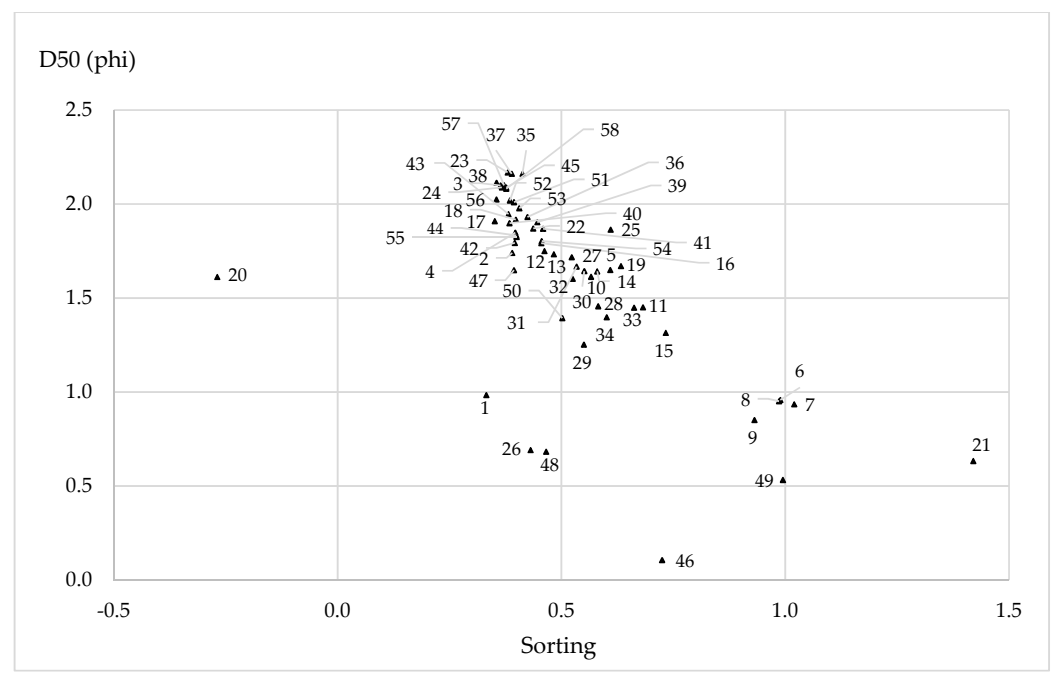

Figure 7. Sedimentological characteristics of analyzed sandy samples. 


\section{Discussion}

Protection of the coastal zone against the impact of sea waves poses a serious challenge in different parts of the world [9]. The use of appropriate protection depends on various factors (e.g., economic, environmental, climatic etc.); therefore, a combination of methods has been increasingly used (the use of several methods of protection at the same time). A combined method to protect the shore from sea erosion was used on the analyzed section of the beach in Rowy. Proper reconstruction of the beach is essential for the operation of holiday towns and resorts, where wide beaches are an attractive tourist destination.

Strong winds from the northern and especially western sectors were involved in the process of covering the forest and the road. Duration of wind at high speed is of great importance, as shown in research by [51]; wind blowing for $24 \mathrm{~h}$ at a speed $>20 \mathrm{~m} \cdot \mathrm{s}^{-1}$ transports as much sand as wind blowing at a speed of $5 \mathrm{~m} \cdot \mathrm{s}^{-1}$ for 660 days. Long-lasting winds blowing at high speed on 4,5 , and 6 October 2016, 27 and 28 November 2016, 27 December 2016 (Storm Barbara), and 4 and 5 January 2017 (Storm Alex) were of the greatest significance in the transport of sand inland. The formulas for calculating full and incomplete saturation of the wind stream proposed by [20] allow determining the amount of transported sand during the year. This is greatly important in managing beaches because it allows estimating the amount of sand carried by the wind inland. As a result, relevant methods can be applied to use natural processes to restore foredunes (e.g., fascine hurdles and strips of grass that stop the transported sand). In the case of construction of new technical infrastructure facilities (descent to the beach), knowledge of the amount of sand transported by the wind allows using appropriate technologies for the construction of these facilities.

Reconstruction of beaches through restoration is designed to protect the shore from marine erosion. Beach superstructure with a height of $3.5 \mathrm{~m}$ constitutes effective protection in the case of the Polish coast of the South Baltic Sea. This value is calculated from the sum of storm surge heights and wind waving [18]. On the shore section in Rowy, beach nourishment contributed to recreating the beach. The replenished beach became more attractive to seaside tourists.

Knowledge of the annual amount of sand transported along the beach and towards the land and sea also allows determining the loss of area/height of the beach and quickly performing another beach restoration using beach nourishment. Otherwise, the beach surface lowered by the wind will be washed out faster by storm waves. It is also very important to grain the sand taken from the shoreface and deposited on the beach. Granularity should be close to natural beach sand [37]. Too fine sand will be blown away faster or washed away by storm waves. In turn, a beach built of coarse-grained sand and fine gravel is not an attractive place for tourists.

The main task of beach nourishment is protecting seashores from flooding (Netherlands) and preventing seashore erosion [37]. Aeolian processes cause the beach to drop down and allow transportation of sand: (1) into the sea (land-sea winds), (2) along the shore (winds parallel to the beach axis), and (3) to foredunes and to land (sea-land winds).

As for the positive aspects of beach nourishment, it should be mentioned that in many places on the Polish coast, beaches were and are narrow due to marine erosion, especially on the scarp coast after storm seasons. A beach that is built up and widened during beach nourishment is conducive to tourists during the summer. It usually has a width of 20-50 m and is gently sloping [18]. An artificially-raised beach also protects dunes and the scarp against further erosion. The results of research conducted by [19] showed that sand from the nourished beach, in windy conditions beneficial for the functioning of aeolian processes, contributes to the accelerated superstructure of the foredune (e.g., in Dziwnów, Łeba, Jurata). The vertical rise of the slope and the dune's crown may reach $0.2 \mathrm{~m}$ (Dziwnów in 2005 and 2006). Beach nourishment also demonstrates positive effects on the cliff coast. In Trzesacz (2012/2013), sand was blown from the restored beach to the strip and wall of gabions that protected the scarp against erosion for the whole year. Established aeolian foredunes with a height of $0.3-0.5 \mathrm{~m}$ were formed [52], and they additionally played a protective role. At the same time, aeolian processes cause 
a gradual reduction of the beach level (in Kołobrzeg during six months, the beach decreased by $0.1 \mathrm{~m}$ due to aeolian processes) [18], and in Rowy, even by $0.25 \mathrm{~m}$.

The artificially built-up beach at the same time turns out to be sensitive to storm conditions. Intense interaction of the waves causes the formation of micro-cliffs with sizes reaching up to the height of the material piled up during beach nourishment. Sandy scarps that are 2-3 $\mathrm{m}$ high make it difficult for tourists to use the beach. It is also related to the fact that the zone from which sand is collected is in contact with coastal shallows. This causes an increase in wave strength. In addition, in the tested example, it was found that the restoration of the beach without biotechnical protection resulted in increased aeolian transport inland, which led to the accumulation of sand in the forest that covered the dune, on the road, and in holiday centers. The next years will demonstrate the reaction of the forest to sand. In addition, aeolian processes generated material losses connected with sand backfilling the forest (the forest was backfilled with $6000 \mathrm{~m}^{3}$ of sand, which given the cost of beach nourishment being 10-15 EUR per $1 \mathrm{~m}^{3}$ totals EUR 60-90 thousand). Backfilling of the road by sand, apart from costs related to the loss of beach surface area, generated additional costs of clearing the sand off the road and transporting it away.

\section{Conclusions}

Rowy is a tourist destination, with several thousand people a day visiting in the summer, spending their time mainly sunbathing. As a result of hydrometeorological factors, the beach in the western part of the town has been almost completely destroyed. To prevent the absorption of land by the sea, the beach was restored using various methods of protection, including beach nourishment. The beach was secured from the impact of the sea. The reconstruction resulted in the creation of two levels of the beach. This contributed to the activation of aeolian processes, even at the lowest wind speeds.

The upper level of the beach has been built up too high in relation to the level of the forest. This was the main reason for the forest being covered with sand. There was also no biotechnical element (fascine hurdles and tree branches for capturing sand) at the border between the restored beach and the forest. For the above reasons, sand, which in normal conditions should be accumulated at the foot of the dunes, was accumulated in the forest. Stronger winds transported the sand beyond the forest, filling the access road to holiday resorts.

The results of our research indicate that poorly-executed accumulative or erosive protection of the sea shore in the beach zone must be supported by preliminary testing of meteorological factors. In addition to meteorological factors, future morphology should also be considered in beach restoration. In the Baltic Sea zone, sandy coasts, as well as coasts destroyed by the sea occur in other countries, which may also encounter poorly-managed seacoast protection. Beach reconstruction must be well-designed because errors in reconstruction will generate high costs in the future.

Author Contributions: Conceptualization, M.H. and M.R.; data curation, M.H. and M.R.; formal analysis, M.H. and M.R.; funding acquisition, M.H. and M.R.; investigation, M.H. and M.R.; methodology, M.H. and M.R.; project administration, M.H. and M.R.; resources, M.H. and M.R.; validation, M.H. and M.R.; visualization, M.H. and M.R.; writing, original draft, M.H., M.R., and A.K.; writing, review and editing, M.H., M.R., and A.K.

Funding: The APC was funded by the Polish Ministry of Science (Project Supporting Maintenance of Research Potential of the Department of Physical Edu., Health and Tourism at Kazimierz Wielki University, No. BS/2016/N1).

Acknowledgments: Hydrometeorological data were obtained from the Institute of Meteorology and Water Management, National Research Institute in Warsaw.

Conflicts of Interest: The authors declare no conflict of interest.

\section{References}

1. Rosentau, A.; Muru, M.; Gauk, M.; Oja, T.; Liibusk, A.; Kall, T.; Karro, E.; Roose, A.; Sepp, M.; Tammepuu, A.; et al. Sea-Level Change and Flood Risks at Estonian coastal Zone. In Coastline Changes of the Baltic Sea from South to East_Past and Future Projection; Harff, J., Furmanczyk, K., von Storch, H., Eds.; Springer: Cham, Switzerland, 2017; Volume 19, pp. 363-388, ISBN 978-3-319-49894-2. 
2. Hünicke, B.; Zorita, E.; von Storch, H. The challenge of Baltic Sea level change. In Coastline Changes of the Baltic Sea from South to East_Past and Future Projection; Harff, J., Furmanczyk, K., von Storch, H., Eds.; Springer: Cham, Switzerland, 2017; Volume 19, pp. 37-54, ISBN 978-3-319-49894-2.

3. Deng, J.; Harff, J.; Zhang, W.; Schneider, R.; Dudzinska-Nowak, J.; Giza, A.; Terefenko, P.; Furmańczyk, K. The dynamic equilibrium shore model for the reconstruction and future projection of coastal morphodynamics. In Coastline Changes of the Baltic Sea from South to East_Past and Future Projection; Harff, J., Furmańczyk, K., von Storch, H., Eds.; Springer: Cham, Switzerland, 2017; Volume 19, pp. 87-106, ISBN 978-3-319-49894-2.

4. Łabuz, T.A. Environmental Impacts-Coastal Erosion and Coastline Changes. In Second Assessment of Climate Change for the Baltic Sea Basin; The BACC II Author Team, Ed.; Regional Climate Studies; Springer: Cham, Switzerland, 2015; pp. 383-396. [CrossRef]

5. Subotowicz, W. Litodynamika brzegów klifowych wybrzeża Polski; Gdańskie Towarzystwo Naukowe, Ossolineum: Wrocław, Poland, 1982; pp. 1-150, ISBN 83-04-01301-0.

6. Rotnicki, K.; Borzyszkowska, W. Accelerated Sea-Level Rise and Its Components at the Polish Baltic Coast in the Years 1951-1990. In Ewolucja Geosystemów Nadmorskich Południowego Bałtyku; Borówka, R.K., Młynarczyk, Z., Wojciechowski, A., Eds.; Bogucki Wydawnictwo Naukowe: Poznań-Szczecin, Poland, 1999; pp. 141-160, ISBN 83-88163-02-7.

7. Koraim, A.S.; Heikal, E.M.; AboZaid, A. Different methods used for protecting coast from sea level rise caused by climate change. Curr. Dev. Oceanogr. 2011, 3, 33-66.

8. Łabuz, T.A. Coastal Response to Climatic Changes: Discussion with Emphasis on Southern Baltic Sea. Landf. Anal. 2012, 21, 43-55.

9. Masria, A.; Negm, A.; Iskander, M.M.; Saavedra, O.C. Coastal protection measures, case study (Mediterranean zone, Egypt). J. Coast. Conserv. 2015, 19, 281-294. [CrossRef]

10. Wolski, T. Temporal and Spatial Characterization of Extreme Baltic Sea Levels; Scientific Publisher of the University of Szczecin: Szczecin, Poland, 2017; pp. 1-265, ISBN 978-83-7972-091-0.

11. Łabuz, T.A.; Grunewald, R.; Bobykina, V.; Chubarenko, B.; Česnulevičius, A.; Bautrenas, A.; Morkunaite, R.; Tõnisson, H. Coastal dunes of the Baltic Sea shores: A review. Quaest. Geogr. 2018, 37, 47-71. [CrossRef]

12. Kolander, R.; Morche, D.; Bimböse, M. Quantification of moraine cliff coast erosion on Wolin Island (Baltic Sea, northwest Poland). Baltica 2013, 26, 37-44. [CrossRef]

13. Uścinowicz, G.; Kramarska, R.; Kaulbarsz, D.; Jurys, L.; Frydel, J.; Przezdziecki, P.; Jegliński, W. Baltic Sea coastal erosion; a case study from Jastrzębia Góra region. Geologos 2014, 20, 259-268. [CrossRef]

14. Kostrzewski, A.; Zwoliński, Z.; Winowski, M.; Tylkowski, J.; Samołyk, M. Cliff top recession rate and cliff hazards for the sea coast of Wolin Island (Southern Baltic). Baltica 2015, 28, 109-120. [CrossRef]

15. Florek, W.; Kaczmarzyk, J.; Majewski, M.; Olszak, I.J. Lithological and extreme event control of changes in cliff morphology in the Ustka region. Landf. Anal. 2008, 7, 53-68.

16. Frydel, J.J.; Mil, L.; Szarafin, T.; Koszka-Maroń, D.; Przyłucka, M. Spatiotemporal differentiation of cliff erosion rate within the Ustka Bay near Orzechowo. Landf. Anal. 2017, 34, 3-14. [CrossRef]

17. Zawadzka-Kahlau, E. Morphodynamics of Southern Baltic Dune Coasts; Wydawnictwo Uniwersytetu Gdańskiego: Gdańsk, Poland, 2012; pp. 1-353, ISBN 978-83-7865-016-4.

18. Łabuz, T. Sposoby ochrony brzegów morskich i ich wpływ na środowisko przyrodnicze polskiego wybrzeża Bałtyku; WWF: Warszawa, Poland, 2013; pp. 1-182.

19. Florek, W.; Kaczmarzyk, J.; Majewski, M.; Schiefelbein, L. Efektywność abrazji na wschód od Ustki. In Geoekosystem Wybrzeży Morskich; Kostrzewski, A., Zwoliński, Z., Winowski, M., Eds.; Wydawnictwo UAM: Poznań-Biała Góra, Poland, 2013; Volume 2, ISBN 978-83-932529-1-6.

20. Rotnicka, J. Aeolian Sand Transport on a Tideless Beach: Rate, Controlling Factors and Influence on Foredune Formation (Łeba Barrier Case, Poland); Bogucki Wyd. Nauk.: Poznań, Poland, 2013; ISBN 978-83-63400-71-2.

21. Wiśniewski, B.; Wolski, T. Occurrence probability of maximum sea levels in Polish ports of Baltic Sea coast. Pol. Mar. Res. 2009, 3, 62-69. [CrossRef]

22. Zeidler, R.; Wróblewski, A.; Mietus, M.; Dziadziuszko, Z.; Cyberski, J. Wind, wave and storm regime at the Polish Baltic coast. J. Coast. Res. 1995, 22, 33-56.

23. Jednorał, T. Metody ochrony polskich brzegów morskich przed spiętrzeniami sztormowymi; Instytut Morski: Gdańsk, Poland, 1990.

24. Jankowski, A. Model Diagnostyczny prądów wiatrowych i gęstościowych na Morzu Bałtyckim. Ph.D. Thesis, Inst. Geofizyki PAN, Warsaw, Poland, 1979. 
25. Kozłowska, A. Prądy morskie południowego Bałtyku. Studia I Mater. Oceanol. 1988, 52, 67-114.

26. Mika, M. Przemiany pod wplywem turystyki na obszarach recepcji turystycznej; Kurek, W., Ed.; Turystyka, Wyd. Naukowe PWN: Warszawa, Poland, 2007; pp. 406-482, ISBN 9788301152949.

27. Durydiwka, M.; Duda-Gromada, K. Influence of tourism on the spatial development of seaside resorts: Selected Aspects. Tourism 2014, 24, 59-65. [CrossRef]

28. Szruba, M. Sposoby ochrony brzegów morskich. Nowocz. Bud. Inżynieryjne 2017, 60-63.

29. Efekty projektów zabezpieczania brzegów morskich zagrożonych erozja-Perspektywa PO IiŚ 2007-2013; Ministerstwo Ochrony Środowiska: Warszawa, Poland, 2016; pp. 1-149.

30. Cieślak, A. Zachowanie i odtwarzanie plaż w wieloletnim programie ochrony brzegów morskich-Założenia i realizacja. Czas Morza 2005, 2, 21-23.

31. Chu, D.T.; Himori, G.; Saito, Y.; Bui, T.V.; Aoki, S. Study of Beach Erosion and Evolution of Beach Profile Due to Nearshore Bar Sand Dredging. Procedia Eng. 2015, 116, 285-292. [CrossRef]

32. Benedet, L.; Finkl, C.W.; Dobrochinski, J.P.H. Optimization of nearshore dredge pit design to reduce impacts on adjacent beaches. J. Coast. Res. 2013, 29, 519-525. [CrossRef]

33. Hanson, H.; Brampton, A.; Capobianco, M.; Dette, H.H.; Hamm, L.; CLaustrup, C.; Lechuga, A.; Spanhoff, R. Beach nourishment projects, practices, and objectives-A European overview. Coast. Eng. 2002, 47, 81-111. [CrossRef]

34. Ostrowski, R.; Pruszak, Z.; Babakow, A. Conditions of seashores and methods of their protection in Kaliningrad Oblast and Lithuania. Inżynieria Morska I Geotech. 2013, 3, 191-197.

35. Van der Wal, D. Beach-dune interactions in nourishment areas along the Dutch coast. J. Coast. Res. 2004, 35, 317-325. [CrossRef]

36. Davison, A.T.; Nichhols, R.J.; Leatherman, S.P. Beach nourishment as a coastal management tool: An annotated bibliography on developments associated with the artificial nourishment of beaches. Technical communication. J. Coast. Res. 1992, 8, 984-1022.

37. Van der Wal, D. Aeolian Transport of Nourishment Sand in Beach-Dune Environments; University of Amsterdam: Amsterdam, The Netherlands, 1999; pp. 1-157, ISBN 90-6787-053-6.

38. Smyth, T.A.; Hesp, P.A. Aeolian dynamics of beach scraped ridge and dyke structures. Coast. Eng. 2015, 99, 38-45. [CrossRef]

39. Davidson-Arnott, R.G.D.; Law, M.N. Seasonal patterns and controls on sediment supply to coastal foredunes, Long Point, Lake Erie. In Coastal Dunes; form and Process; Nordstrom, K.F., Psuty, N.P., Carter, R.W.G., Eds.; Wiley: Chichester, UK, 1990; pp. 177-200, ISBN 978-0-471-91842-4.

40. Van der Wal, D. Effects of fetch and surface texture on aeolian sand transport on two nourished beaches. J. Arid Environ. 1998, 39, 533-547. [CrossRef]

41. Draga, M. Aeolian activity as a consequence of beach nourishment-Observations at Westerland (Sylt), German North Sea coast. Z. Für Geomorphol. 1983, 22, 303-319.

42. Pilch, M. Ochrona brzegów morskich georurą SoilTain ${ }^{\circledR}$ na przykładzie zabezpieczenia wydmy w Rowach. Inżynieria Morska I Geotech. 2013, 4, 306-313.

43. Rudowski, S.; Wróblewski, R. The necessity of sea coast and bottom nomenclature enhancement on Ustecka Bay example. In Geologia i geomorfologia Pobrzeża i południowego Bałtyku; Florek, W., Ed.; Wydawnictwo Naukowe Akademii Pomorskiej: Słupsk, Poland, 2012; Volume 9, pp. 57-59, ISBN 978-83-7467-185-9.

44. Rotnicki, K. Problem of the Holocene transgressions at the Polish Baltic middle coast in the light of new data from the Gardno-Łeba Coastal Plain. In Ewolucja geosystemów nadmorskich Potudniowego Bałtyku; Borówka, R.K., Młynarczyk, Z., Wojciechowski, A., Eds.; Bogucki Wydawnictwo Naukowe: Poznań-Szczecin, Poland, 1999; pp. 121-139, ISBN 83-88163-02-7.

45. Folk, R.L.; Ward, W.C. Brazos River bar [Texas]; A study in the significance of grain size parameters. J. Sediment. Res. 1957, 27, 3-26. [CrossRef]

46. Dane publiczne IMGW-PIB. Available online: https://danepubliczne.imgw.pl (accessed on 24 August 2018).

47. Hojan, M.; Tylkowski, J.; Rurek, M. Hydrometeorological conditions for the occurrence of aeolian processes on the Southern Baltic Coast in Poland. Water 2018, 10, 1745. [CrossRef]

48. Ludwig, J.; Lindhorst, S.; Betzler, C.; Bierstedt, S.E.; Borówka, R.K. Sedimentary rhythms in coastal dunes as a record of intra-annual changes in wind climate (Łeba, Poland). Aeolian Res. 2017, 27, 67-77. [CrossRef]

49. Hesp, P.A.; Smyth, T.A.; Nielsen, P.; Walker, I.J.; Bauer, B.O.; Davidson-Arnott, R. Flow deflection over a foredune. Geomorphology 2015, 230, 64-74. [CrossRef] 
50. Bagnold, R.A. The Physics of Blown Sand and Desert Dunes; Chapmann and Hall: London, UK, 1941.

51. Borówka, R.K. Present day dune processes and dune morphology on the Łeba Barrier, polish coast of the Baltic. Geogr. Ann. 1980, 62A, 75-82. [CrossRef]

52. Łabuz, T.A. Morphodynamics and rate of Cliff erosion in Trzęsacz (1997-2017). Landf. Anal. 2017, 34, $29-50$. [CrossRef] 